\title{
Wegener's granulomatosis and retroperitoneal fibrosis: a case report and review of the literature
}

\author{
Lia Salvati, ${ }^{1}$ Valeria Ludovici, ${ }^{1}$ Giuliana Properzi, ${ }^{1}$ Laura Natali, ${ }^{2}$ Angelo Viscido,,${ }^{1}$ Claudio Ferri ${ }^{1}$ \\ ${ }^{1}$ Internal Medicine Division, Department of Life, Health and Environmental Sciences, University of L'Aquila; ${ }^{2}$ Internal Medicine \\ Division, S. Salvatore Hospital, L'Aquila, Italy
}

\begin{abstract}
Granulomatosis with polyangiitis (GPA), also known as Wegener's granulomatosis (WG), is a rare systemic auto-inflammatory disease characterized by necrotizing granulomatous inflammation and antineutrophil cytoplasmic antibodies-associated small vessel vasculitis. Retroperitoneal fibrosis (RPF) is an uncommon collagen vascular disease of unclear etiology, characterized by a chronic non-specific inflammation of the retroperitoneum, which can entrap and obstruct retroperitoneal structures, notably abdominal aorta, iliac arteries and ureters. RPF is mostly idiopathic, but an association with vasculitis has been shown. However, only few cases of retroperitoneal fibrosis with ureterohydronephrosis secondary to GPA have been described in literature. The outcome seems to be better when compared to the idiopathic form, and immunosuppressive treatment demonstrated to be effective, with low need in surgery. We provide the case report of a 57-year-old patient, affected by GPA, referred to our Division for massive vein thrombosis and ureteral stenosis secondary to retroperitoneal fibrosis. We also provide a review of the literature currently available on this topic.
\end{abstract}

\section{Introduction}

Granulomatosis with polyangiitis (GPA) is a rare systemic auto-inflammatory disease characterized by necrotizing granulomatous inflammation and antineutrophil cytoplasmic antibodies (ANCA)-associated small vessel vasculitis. ${ }^{1}$ GPA affects both genders equally, and the mean age at onset is within the fourth decade. Its worldwide prevalence is estimated to be

Correspondence: Lia Salvati, Internal Medicine Division, Department of Life, Health and Environmental Sciences, University of L'Aquila, via Beffi 3, 67100 L'Aquila, Italy.

E-mail: liasal88@gmail.com

Key words: Vasculitis; retroperitoneal fibrosis; rheumatology; ureterohydronephrosis; tamoxifen.

Contributions: VL, LS contributed equally to this paper; LN, GP contributed to the final version; $\mathrm{CF}, \mathrm{AV}$ reviewed the paper. All authors read and approved the final version to be published.

Conflict of interests: the authors declare no conflict of interests.

Received for publication: 27 January 2019.

Accepted for publication: 28 January 2019.

This work is licensed under a Creative Commons Attribution NonCommercial 4.0 License (CC BY-NC 4.0).

(C) Copyright L. Salvati et al., 2019

Licensee PAGEPress, Italy

Italian Journal of Medicine 2019; 13:109-115

doi:10.4081/itjm.2019.1138
23.7-156.5 per million, with an estimated annual incidence of 3.0-14.4 per million., ${ }^{2,3}$ The etiology remains unknown although a number of exogenous factors, such as exposure to infectious agents or environmental factors have been supposed to be relevant in the pathogenesis of the disease. Diagnosis might be challenging because of the broad spectrum of clinical characteristics that ranges from predominantly granulomatous manifestations restricted to the respiratory tract (localized disease) to severe, life-threatening necrotizing vasculitis affecting many organs, with a predilection for lung and kidney involvement (alveolar hemorrhage and crescentic glomerulonephritis). ${ }^{1}$ It may also impact other organs like skin or peripheral nerves, but it rarely involves the urological area. Nevertheless, GPA may affect large blood vessels such as the aorta or vena cava. Ureters may also be compressed by the large inflammatory mass. In GPA, ANCA are mainly directed against proteinase 3 (PR3); there is strong evidence from in vitro studies that ANCA play a crucial role in the mediation of smallvessel vasculitis. ${ }^{4}$ The consensus classification of GPA by the American College of Rheumatology requires at least two of the following four criteria: abnormal urinary sediment (microscopic hematuria or proteinuria), abnormal findings on chest radiography, oral ulcers or nasal discharge, and granulomatous inflammation on biopsy. ${ }^{5}$ In that respect, our case qualified for a diagnosis of GPA. Despite the large amount of new potential therapies, cyclophosphamide and corticosteroids remain the most recognized and effective means of inducing and sustaining remission of GPA. ${ }^{6}$

Chronic periaortitis is an umbrella term used to de- 
scribe a group of nosologically allied conditions that include idiopathic retroperitoneal fibrosis (Ormond's disease), inflammatory abdominal aortic aneurysm, and perianeurysmal retroperitoneal fibrosis. ${ }^{7}$ Retroperitoneal fibrosis (RPF) is an uncommon collagen vascular disease of unclear etiology. It is characterized by a chronic non-specific inflammation of the retroperitoneum, which can entrap and obstruct retroperitoneal structures, notably abdominal aorta, iliac arteries and ureters. The idiopathic form accounts for over $70 \%$ of cases of retroperitoneal fibrosis. According to a Finnish study, the estimated incidence of idiopathic retroperitoneal fibrosis is 0.1 per 100,000 person-years. Men are affected twice to three times more often than women and the mean age at presentation is 50-60 years, although reports on the condition in children and older adults are not uncommon. ${ }^{8}$ Retroperitoneal fibrosis is generally idiopathic, but can also be secondary to the use of certain drugs, malignant diseases, auto-inflammatory diseases, infections, and surgery. Irrespective of its cause, most cases of non-malignant RPF - if in the active cellular stage - will respond to treatment with corticosteroids, with no need for surgical treatment. Accumulating data suggest alternative treatment strategies for steroid-resistant cases (i.e. intensive immunosuppression) or when steroids are not feasible (i.e. other forms of immunosuppression or hormonal treatment, particularly tamoxifen). Although early diagnosis and treatment provide excellent renal and patient outcome, longterm follow-up is mandatory in all cases. ${ }^{9}$

Little is known about the association between GPA and RPF. Only few cases of retroperitoneal fibrosis with ureterohydronephrosis secondary to GPA have been described in literature. Neither the diagnostic algorithm nor the therapeutic approach is standardized. Thus, we provide the case report of a 57-year-old patient, affected by GPA, referred to our Division for massive vein thrombosis and ureteral stenosis secondary to retroperitoneal fibrosis. We also provide a systematic review of the literature on this topic.

\section{Case Report}

A 57-year-old Caucasian woman was referred to our Division in April 2016 for right upper leg inflammation. Medical history was positive for arterial hypertension, type 2 diabetes. Four years before, the patient was also diagnosed with Wegener's granulomatosis, with pulmonary infiltration, oral ulcers and granulomatous inflammation on skin biopsy, currently treated with low dose corticosteroids and methotrexate (15 mg/week). Physical examination showed right leg edema and flushing, and no other relevant clinical findings. Familiar history was positive for ischemic cardiomyopathy and type 2 diabetes.
Laboratory tests indicated modest neutrophilia, elevation of inflammatory markers (erythrocyte sedimentation rate: $33 \mathrm{~mm} / \mathrm{h}$, fibrinogen: $664 \mathrm{mg} / \mathrm{dL}$ ) and D-dimer (2006 ng/mL). Serum concentration of urea, creatinine, and electrolytes were within normal limits. Anti-neutrophil cytoplasmic antibodies (c-ANCA) were markedly increased (86 U.A./mL, reference range $<20$ U.A./mL).

An ultrasound was performed and showed deep vein thrombosis of the common and superficial femoral vein and popliteal vein. A computed tomography angiography excluded pulmonary embolism, revealing extensive thrombosis involving superficial and deep femoral vein, iliac vein and inferior vena cava; the exam showed the presence of retroperitoneal solid tissue around abdominal aorta, inferior vena cava, sheathing left ureter and causing alithiasic ureterohydronephrosis. A positron emission tomography scan showed weak and patchy tracer uptake of the retroperitoneal tissue (Figures 1-3).

IgG4 levels were within normal range. Urine cy-

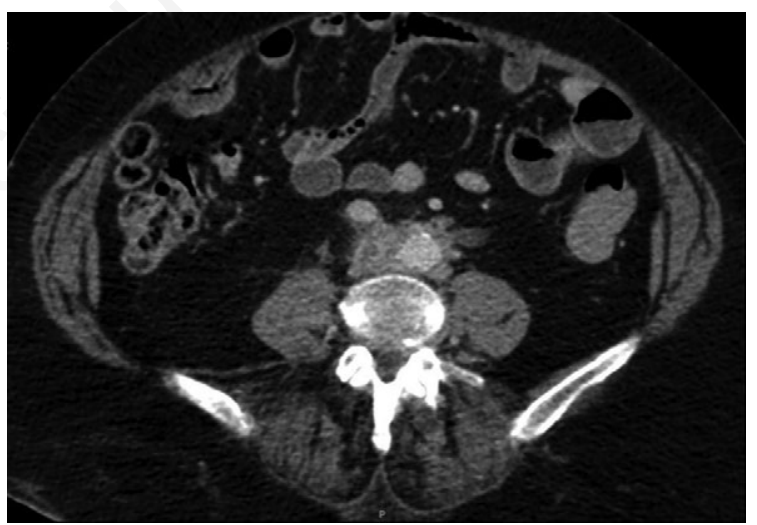

Figure 1. Abdomen computed tomographic scan showing retroperitoneal fibrosis.

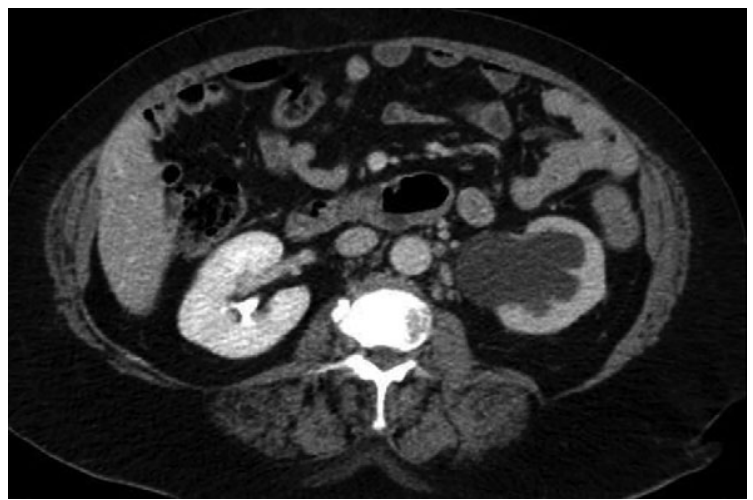

Figure 2. Abdomen computed tomographic scan showing hydroureteronephrosis. 
tology showed nonspecific inflammatory and dystrophic cells and was not suggestive of a transitional cell carcinoma. Thrombophilia screen was performed: lupus anticoagulant ratio was 1 and antiphospholipid screen revealed IgG levels $3.3 \mathrm{U} / \mathrm{mL}$ and IgM levels $1.4 \mathrm{U} / \mathrm{mL}$; prothrombin (FII), factor V Leiden and methylene tetrahydrofolate reductase mutation tests showed wild-type homozygosis; protein $\mathrm{C}$ and protein $\mathrm{S}$ activity determination were within normal range respectively ( $117 \%$ and $58 \%)$.

A retroperitoneal fibrosis secondary to GPA complicated by ureterohydronephrosis and deep vein thrombosis was diagnosed. A urinary diversion was performed using a double J endoureteral stent. Highdose intravenous corticosteroids (prednisone $1 \mathrm{mg} / \mathrm{kg}$ QD), tamoxifen (10 mg BID) and oral anticoagulant therapy with apixaban (10 mg QD) were started. At the time of GPA diagnosis, the patient was started on cyclophosphamide, but she experimented hematological

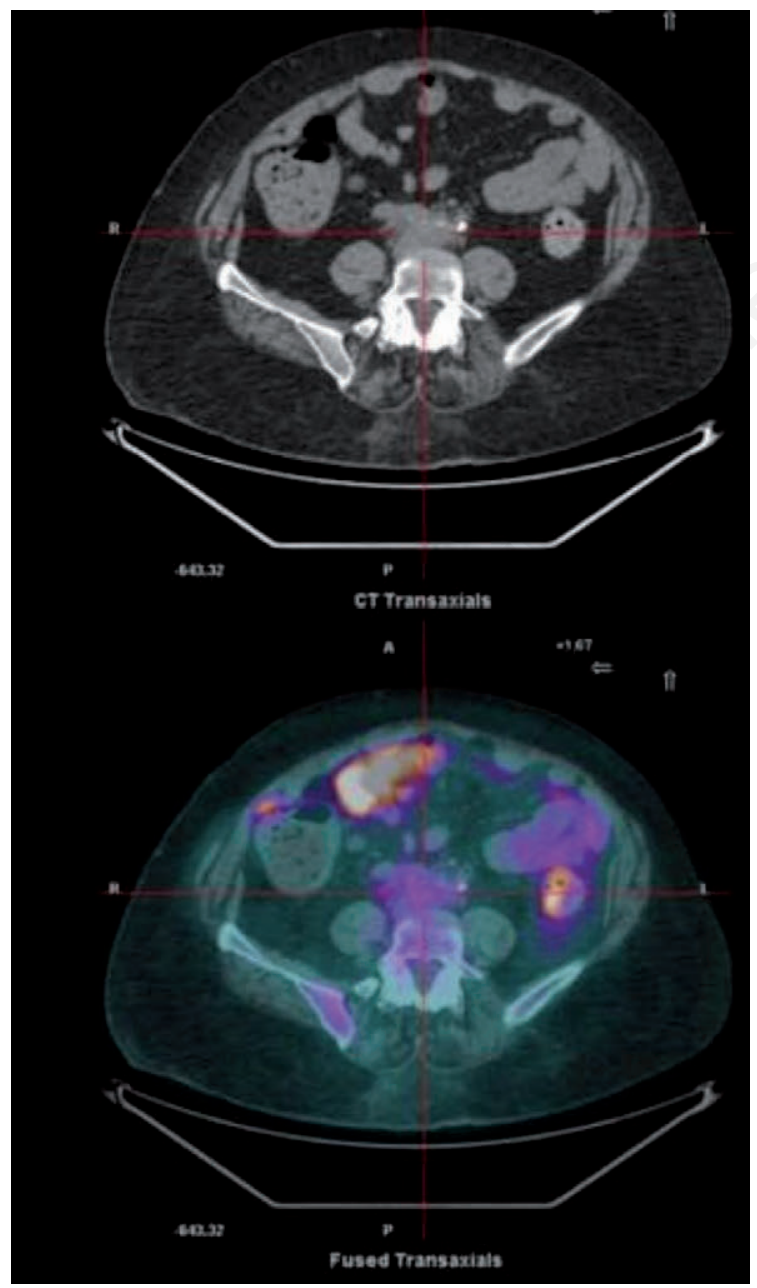

Figure 3. Positron emission tomography-computed tomographic scan showing retroperitoneal F18-fluorodeoxyglucose uptake. side effects. The ongoing therapy with methotrexate was then continued. The patient gradually improved.

Because of the necessity of anticoagulant therapy, and seen the rapid improvement in clinical conditions, a biopsy of the retroperitoneal mass was not performed.

A new computed tomographic (CT) scan was performed after two months, in order to evaluate the evolution of the abdominal situation. It revealed regression of ureterohydronephrosis, complete recanalization of deep vein thrombosis and persistence of retroperitoneal fibrosis (to reassess with long-term follow-up).

\section{Discussion}

Little is known about the association between GPA and retroperitoneal fibrosis. Indeed, the relation between retroperitoneal fibrosis and vasculitis is intriguing and complex. Systemic vasculitis may present as a tumor-like mass, miming fibrotic tissue. In 2000 Kariv et al. reviewed this association in 83 patients. ${ }^{10}$ The most common vasculitis presenting as tumor-like lesions were Wegener's granulomatosis $(35 \%)$ and giant cell arteritis (21\%). GPA was distinct for the diversity of tumor-like locations, affecting 12 different sites, with a prevalence of breast, pulmonary, mediastinal, and renal masses; only 1 case presented with GPA and retroperitoneal mass. Conversely, although RPF pathogenesis is unknown, it has often been suggested that immunological mechanisms play a role. ${ }^{8}$ A possible link between RPF, ANCA and small-vessel vasculitis is not surprising when we consider that about $10 \%$ of RPF masses contain overt vasculitic lesions with fibrinoid necrosis in the small vessels. ${ }^{11}$ Furthermore, recent case reports have described isolated RPF associated with positive C- or P-ANCA ${ }^{12,13}$ and RPF associated with defined systemic vasculitis, including Takayasu $\operatorname{arteritis}^{14}$ and c-ANCA or pANCA-positive vasculitis, such as periarteritis nodosa, ${ }^{15}$ Churg-Strauss syndrome ${ }^{16}$ and Wegener's granulomatosis. ${ }^{17}$ Before the availability of ANCAtesting, other cases of RPF associated with vasculitis were reported in which vasculitis involved the small vessels. ${ }^{18}$ The possibility that a vasculitic process may play a role in the pathogenesis of RPF therefore cannot be excluded. Vasculitis could involve the aortic vasa vasorum and retroperitoneal vessels, and thus lead to different pathological pictures, bringing about an aortic aneurysm with marked adventitial inflammation (the pathological hallmark of inflammatory aneurysms) or extending into the retroperitoneum and eliciting a fibrogenic response surrounding other structures (e.g. the ureters or duodenum). The appearance of periaortitis with aortic aneurysm as a consequence of GPA is a very rare complication, likely due to an ANCA-mediated vasculitis of vasa vasorum in 
the aortic wall. Reports in literature have described only few cases of large-vessel aneurysms associated with GPA. ${ }^{19}$ Histology is only available for the cases in which surgical treatment was required, and biopsies of the aortic tissue revealed vasculitis suggestive of GPA..$^{20-24}$ While renal involvement is a cornerstone in GPA presentation and diagnosis, urogenital manifestation in patients with GPA, including prostatitis, orchitis, epididymitis, renal pseudotumor, penile ulceration and ureteral stenosis, are extremely rare. ${ }^{25,26}$ Furthermore, to our knowledge, only 22 documented cases regarding retroperitoneal fibrosis with ureteral stenosis secondary to GPA were found in literature.

As reported in 12 out of the 22 cases described in this report, retroperitoneal fibrosis with ureteral narrowing may appear as the sole preliminary symptom of GPA. ${ }^{18,27,28}$ Vaglio et al. described two cases of RPF associated with ANCA-mediated vasculitis, presenting with ureteral stenosis. In both cases immunosuppressive treatment led to favorable clinical course and improvement in laboratory tests. ${ }^{18}$ Izzedine $e t$ al. reported the case of a 51-year-old man with abdominal pain, urinary symptoms and a constitutional syndrome. Imaging studies revealed retroperitoneal fibrosis. Necrotizing granulomas, giant cells and a lymphoepithelioid cellular infiltrate were observed in biopsy of the retroperitoneal tissue. The patient responded poorly to antituberculous treatment. Finally, a renal biopsy was performed, which revealed pauci-immune rapidly progressive glomerulonephritis with necrotizing vasculitis. Alveolar hemorrhages were observed on thoracic $\mathrm{CT}$ and a diagnosis of GPA was made. The patient presented a significant improvement after treatment with immunosuppressive agents and corticosteroids. ${ }^{28}$ Gonzales Revilla et al. reported a case of GPA onset with pulmonary and periaortic involvement, associated with retroperitoneal fibrosis causing left-sided ureterohydronephrosis; treatment with corticosteroids and methotrexate led to clinical and radiological improvement after 1 month. ${ }^{27}$ We should be aware of the fact that the unique involvement of rarely reported GPA locations may hamper the diagnosis in the absence of classic granulomatous locations such as sinus, lungs and kidneys. Usually ureteral stenosis was reported at the level of iliac artery, however, multilevel or bilateral lesions have also been reported, leading to acute renal failure and anuria. ${ }^{18,25,26}$ Le Thi Huong et al. reported 80 cases with urogenital involvement due to GPA; only 2 cases with ureteral stenosis were found and only one of them had bilateral ureteral involvement. Ureteral double-J stents were inserted for bilateral ureteral obstruction. The treatment was followed by high dose corticosteroid and cyclophosphamide, with complete recovery. ${ }^{25}$ ANCA, mainly PR3, were almost always positive.

No data emerged on the IgG4 profile of these pa- tients, mainly because the current immunoglobulin G4 (IgG4)-testing was not available when most of the cases were described. IgG4-related disease (IgG4-RD) is a newly recognized systemic disorder characterized by a lymphoplasmacytic cell infiltrate abundant in IgG4-positive plasma cells, storiform tissue fibrosis, and variably elevated IgG4 levels in serum. The disease mainly affects kidneys, pancreas, salivary glands, mediastinum and retroperitoneum. A differential diagnosis between ANCA-mediated vasculitis and IgG4$\mathrm{RD}$ is often challenging. Lomborg et al. described the case of a patient, previously diagnosed with GPA (with no granulomas at the biopsy) that secondarily developed a retroperitoneal fibrosis with ureteral stenosis. A biopsy of the tissue was performed, showing abundant infiltration of plasma cells positive for $\mathrm{IgG} 4 .{ }^{29} \mathrm{In}$ a recent study on patients with idiopathic retroperitoneal fibrosis, $57 \%$ had morphological and immunohistochemical stainings compatible with IgG4-RD. ${ }^{30}$ We also have to remark that in most of the reported cases a mass biopsy has not been performed. However, referring to our patient, the previous histological finding of a granulomatous lesion (uncommon in IgG4-RD) and the negativity of IgG4 serum levels strengthened the GPA diagnosis (Table 18,25-28,31-44).

Urogenital complications of Wegener's granulomatosis have been shown to be sensitive to corticosteroid and cyclophosphamide therapy. ${ }^{31,32}$ Because of the toxicity associated with the long-term administration of cyclophosphamide, a number of alternative regimens have been investigated as initial therapy, though none has displaced the regimen of intravenous cyclophosphamide plus oral glucocorticoids. The treatment of choice for patients who cannot receive or who decline cyclophosphamide is rituximab. However, low weekly doses of oral methotrexate have also been used for the initial therapy in patients who do not have renal alterations or severe disease..$^{27,33,34}$ Also tamoxifen (TMX) has shown to be a suitable alternative in idiopathic retroperitoneal fibrosis (iRPF). A recent retrospective trial compared the efficacy of corticosteroids and tamoxifen in monotherapy, concluding that corticosteroids are superior to TMX in treating iRPF disease. However, among patients with initial primary treatment success, recurrence rate was lower in TMX-treated patients. No data are available on the use of tamoxifen in retroperitoneal fibrosis secondary to small vessel vasculitis. However, the impossibility to treat our patient with cyclophosphamide, induced us to use the hormonal therapy with TMX, aiming to block another potential mechanism of the disease. Since a good improvement was rapidly seen, this choice gave us the chance to avoid surgical treatment. In some of these cases, unfortunately, immunosuppressive management was not started right after diagnosis of ureteral obstruction, instead surgery was performed. In most of the cases obstruction com- 
Table 1. Current literature on granulomatosis with polyangiitis.

\begin{tabular}{|c|c|c|c|c|c|c|c|}
\hline Gender & Age & $\begin{array}{l}\text { Ureteral stenosis } \\
\text { as first symptom }\end{array}$ & $\begin{array}{l}\text { Clinical } \\
\text { presentation }\end{array}$ & $\begin{array}{l}\text { Medical } \\
\text { treatment }\end{array}$ & $\begin{array}{l}\text { Surgical } \\
\text { treatment }\end{array}$ & Outcome & References \\
\hline $\mathrm{M}$ & 65 & No & $\begin{array}{l}\text { Lower back pain, } \\
\text { intermittent fever, } \\
\text { weight loss, urinary } \\
\text { hesitancy, dribbling }\end{array}$ & CYC & $\begin{array}{l}\text { Balloon dilatation, } \\
\text { ureteral stent }\end{array}$ & $\begin{array}{l}\text { Resolution of } \\
\text { obstructive syndrome } \\
\text { within } 4 \text { weeks; } \\
\text { symptom free after } \\
11 \text { months without } \\
\text { therapy }\end{array}$ & Middleton, $1994^{36}$ \\
\hline M & 50 & Yes & Abdominal pain & Cortic/CYC & No & $\begin{array}{l}\text { Improvement of } \\
\text { renal function, } \\
\text { hemodialysis } \\
\text { discontinued after } \\
4 \text { months }\end{array}$ & Metselaar, $1985^{31}$ \\
\hline M & 30 & Yes & $\begin{array}{l}\text { Leg pain, nausea, } \\
\text { weight loss, } \\
\text { intermittent fever, } \\
\text { fatigue }\end{array}$ & Cortic/CYC & No & - & Adelizzi, $1986^{37}$ \\
\hline $\mathrm{F}$ & 37 & Yes & $\begin{array}{l}\text { Anuria, intermittent } \\
\text { fever, abdominal } \\
\text { pain, fatigue }\end{array}$ & Cortic/CYC & No & Remission & Leche, $1985^{38}$ \\
\hline M & 49 & Yes & $\begin{array}{l}\text { Persistent pain in } \\
\text { the groin }\end{array}$ & Cortic/CYC & Ureterolysis & $\begin{array}{l}\text { After } 7 \text { years, renal } \\
\text { function deteriorated } \\
\text { and chronic dialysis } \\
\text { was started }\end{array}$ & Ter Maaten, $1993^{39}$ \\
\hline $\mathrm{F}$ & 60 & No & $\begin{array}{l}\text { Fatigue, weakness, } \\
\text { intermittent fever, } \\
\text { sweats and chills }\end{array}$ & Cortic/CYC & $\begin{array}{l}\text { Transureterouret } \\
\text { erostomy }\end{array}$ & Remission & Baker, $1978^{40}$ \\
\hline M & 56 & No & $\begin{array}{l}\text { Renal colic, } \\
\text { hematuria }\end{array}$ & Cortic/CYC & No & $\begin{array}{l}\text { Remission for } 60 \\
\text { months, residual } \\
\text { asymptomatic ureteral } \\
\text { stenosis }\end{array}$ & $\begin{array}{l}\text { Le Thi Huong, } \\
1996^{25}\end{array}$ \\
\hline $\mathrm{F}$ & 72 & No & Anuria & Cortic/CYC & $\begin{array}{l}\text { Surgical therapy } \\
\text { double-J stent }\end{array}$ & $\begin{array}{l}\text { Stent removed after } \\
2 \text { months, } 36 \text { months } \\
\text { later death for acute } \\
\text { espiratory failure }\end{array}$ & $\begin{array}{l}\text { Le Thi Huong, } \\
1996^{25}\end{array}$ \\
\hline M & 51 & Yes & $\begin{array}{l}\text { Abdominal pain, } \\
\text { urinary symptoms, } \\
\text { weight loss, } \\
\text { intermittent fever }\end{array}$ & Cortic/CYC & Double-J stent & $\begin{array}{l}\text { After } 12 \text { months light } \\
\text { improvement in renal } \\
\text { function }\end{array}$ & Izzedine, $2002^{28}$ \\
\hline M & 67 & $\begin{array}{l}\text { No } \\
\text { Under } \\
\text { Cortic/MTX }\end{array}$ & Abdominal pain & Cortic/CYC & Double-J stent & $\begin{array}{l}\text { After } 18 \text { months } \\
\text { complete remission }\end{array}$ & Umemoto, $2012^{32}$ \\
\hline M & 53 & No Under MTX & Asymptomatic & & $\begin{array}{l}\text { Double-J stent } \\
\text { Resection of the } \\
\text { ureteral stricture }\end{array}$ & $\begin{array}{l}\text { After } 106 \text { months } \\
\text { death due to } \\
\text { metastatic carcinoma } \\
\text { of the upper airways }\end{array}$ & Dufour, $2012^{26}$ \\
\hline $\mathrm{F}$ & 71 & Yes & $\begin{array}{l}\text { Right renal colic, } \\
\text { anorexia, loss of } \\
\text { weight, asthenia }\end{array}$ & Cortic/CYC & $\begin{array}{l}\text { Double-J stent } \\
\text { Resection of the } \\
\text { ureteral stricture }\end{array}$ & $\begin{array}{l}\text { After } 6 \text { months } \\
\text { improved renal } \\
\text { function }\end{array}$ & Lillaz, $2011^{41}$ \\
\hline- & - & No & - & Cortic/CYC & & Death for sepsis & Davenport, $1996^{35}$ \\
\hline M & 44 & No & $\begin{array}{l}\text { Severe right } \\
\text { abdominal pain }\end{array}$ & Cortic/MTX & No & $\begin{array}{l}\text { After } 24 \text { months } \\
\text { asymptomatic }\end{array}$ & Farpour, $2014^{33}$ \\
\hline M & 47 & Yes & $\begin{array}{l}\text { Fever, livedo and } \\
\text { skin necrosis of } \\
\text { lower limbs }\end{array}$ & $\begin{array}{l}\text { Cortic/AZA } \\
\text { then } \\
\text { Cortic/CYC }\end{array}$ & No & $\begin{array}{l}\text { After } 24 \text { months } \\
\text { asymptomatic }\end{array}$ & $\begin{array}{l}\text { de Roux-Serratrice, } \\
2002^{42}\end{array}$ \\
\hline M & 21 & Yes & $\begin{array}{l}\text { Fever, fatigue, } \\
\text { diffuse arthralgias, } \\
\text { and myalgias }\end{array}$ & Cortic/CYC & $\begin{array}{l}\text { Double-J stent } \\
\text { Resection of the } \\
\text { ureteral stricture }\end{array}$ & $\begin{array}{l}\text { After } 6 \text { months no } \\
\text { evidence of recurrence }\end{array}$ & Kamar, $2003^{34}$ \\
\hline $\mathrm{F}$ & 59 & Yes & $\begin{array}{l}\text { Fatigue and severe } \\
\text { lower back pain }\end{array}$ & TMP/SMX & $\begin{array}{l}\text { Double-J stent } \\
\text { Resection of the } \\
\text { ureteral stricture }\end{array}$ & $\begin{array}{l}\text { After } 12 \text { months } \\
\text { asymptomatic }\end{array}$ & Kamar, $2003^{34}$ \\
\hline
\end{tabular}


Table 1. Continued from previous page.

\begin{tabular}{|c|c|c|c|c|c|c|c|}
\hline Gender & Age & $\begin{array}{l}\text { Ureteral stenosis } \\
\text { as first symptom }\end{array}$ & $\begin{array}{l}\text { Clinical } \\
\text { presentation }\end{array}$ & $\begin{array}{l}\text { Medical } \\
\text { treatment }\end{array}$ & $\begin{array}{l}\text { Surgical } \\
\text { treatment }\end{array}$ & Outcome & References \\
\hline- & - & No & - & Cortic/CYC & Surgical intervention & - & Hensle, $1978^{43}$ \\
\hline F & 24 & - & - & $\begin{array}{l}\text { Cortic/AZA } \\
\text { Cortic/CYC }\end{array}$ & & - & $\operatorname{Rich}^{44}$ \\
\hline M & 74 & Yes & $\begin{array}{l}\text { Continuous pain } \\
\text { over the right renal } \\
\text { angle, associated } \\
\text { with dark urine }\end{array}$ & Cortic/MTX & $\begin{array}{l}\text { Retroperitoneal } \\
\text { mass biopsy }\end{array}$ & $\begin{array}{l}\text { Radiological and } \\
\text { clinical improvement } \\
\text { after } 1 \text { month }\end{array}$ & $\begin{array}{l}\text { Gonzales-Revilla, } \\
2016^{27}\end{array}$ \\
\hline $\mathrm{F}$ & 74 & Yes & $\begin{array}{l}\text { Fever, oliguria, } \\
\text { asthenia and } \\
\text { anorexia }\end{array}$ & Cortic/CYC & Double-J stent & $\begin{array}{l}\text { Radiological and } \\
\text { clinical improvement } \\
\text { after } 18 \text { months }\end{array}$ & Vaglio, $2002^{18}$ \\
\hline M & 57 & Yes & $\begin{array}{l}\text { Asthenia, abdominal } \\
\text { pain and dyspnea } \\
\text { Acute renal failure }\end{array}$ & $\begin{array}{l}\text { Hemodialysis } \\
\text { Cortic/CYC }\end{array}$ & $\begin{array}{l}\text { Right percutaneous } \\
\text { pyelostomy, ureteral } \\
\text { stenting renal biopsy }\end{array}$ & $\begin{array}{l}50 \% \text { reduction in the } \\
\text { retroperitoneal mass } \\
\text { after } 6 \text { months }\end{array}$ & Vaglio, $2002^{18}$ \\
\hline
\end{tabular}

CYC, cyclophosphamide; MTX, methotrexate; AZA, azathioprine; TMP/SMX, trimethoprim/sulfamethoxazole.

pletely resolved after immunosuppressive therapy except one case. ${ }^{35}$ Davenport et al. reported 8 GPA cases with urogenital involvement, one of them with retroperitoneal involvement and ureteral obstruction; the patient was started on immunosuppressive therapy but unfortunately died of sepsis. ${ }^{35}$ Only one case ended up with surgery while on immunosuppressive therapy. Dufour et al. evaluated 11 patients with urogenital manifestation of GPA; only one patient presented ureteral obstruction. Immunosuppressive therapy with prednisone and methotrexate was maintained. A double-J ureteral stent was inserted. However, after 6 months the resection of the stricture with end-to-end anastomosis was done due to persistence of ureteral obstruction. ${ }^{26}$ However, in this case, no change in immunosuppressive therapy was made prior to surgery, and surgical treatment could have been possibly avoided by a change in immunosuppressive management.

\section{Conclusions}

To summarize, we presented a case of GPA with retroperitoneal fibrosis that led to hydronephrosis and deep vein thrombosis. We also reviewed the current literature on this topic. Ureteral obstruction usually resolves with stenting and immunosuppressive therapy. Although data on follow up are often missing or incomplete, a low recurrence rate of ureteral stenosis after treatment was observed in the cases reported. It seems logical to consider medical management as a first line therapy in any urologic involvement of GPA, although in patients with persistent symptoms surgical procedures should be regarded. However, further investigations are required to confirm this consideration. Furthermore, we always suggest evaluating the possible diagnosis of IgG4-RD, as clinical features of this disease often overlap with RFP and GPA.

\section{References}

1. Almouhawis HA, Leao JC, Fedele S, Porter SR. Wegener's granulomatosis: a review of clinical features and an update in diagnosis and treatment. J Oral Pathol Med 2013;42:507-16.

2. Mahr AD. Epidemiological features of Wegener's granulomatosis and microscopic polyangiitis: two diseases or one 'anti-neutrophil cytoplasm antibodies-associated vasculitis’ entity? APMIS Suppl 2009;127:41-7.

3. Grisaru S, Yuen GW, Miettunen PM, Hamiwka LA. Incidence of Wegener's granulomatosis in children. J Rheumatol 2010;37:440-2.

4. Calderwood JW, Williams JM, Morgan MD, et al. ANCA induces beta2 integrin and CXC chemokine-dependent neutrophil-endothelial cell interactions that mimic those of highly cytokine-activated endothelium. J Leukoc Biol 2005;77:33-43.

5. Leavitt RY, Fauci AS, Bloch DA, et al. The American College of Rheumatology 1990 criteria for the classification of Wegener's granulomatosis. Arthritis Rheum 1990;33:1101-7.

6. Miszalski-Jamka T, Szczeklik W, Sokołowska B, et al. Cardiac involvement in Wegener's granulomatosis resistant to induction therapy. Eur Radiol 2011;21:2297-304.

7. Vaglio A, Buzio C. Chronic periaortitis: a spectrum of diseases. Curr Opin Rheumatol 2005;17:34-40.

8. Gilkeson GS, Allen NB. Retroperitoneal fibrosis. A true connective tissue disease. Rheum Dis Clin North Am 1996;22:23-38.

9. van Bommel EF. Retroperitoneal fibrosis. Neth J Med 2002;60:231-42.

10. Kariv R, Sidi Y, Gur H. Systemic vasculitis presenting as a tumorlike lesion. Four case reports and an analysis of 79 reported cases. Medicine (Baltimore) 2000;79:349-59.

11. Lindell OI, Sariola HV, Lehtonen TA. The occurrence of vasculitis in perianeurysmal fibrosis. J Urol 1987;138:727-9.

12. Sakemi T, Tomiyoshi Y, Yano H, et al. Retroperitoneal fibrosis with perinuclear antineutrophil cytoplasmic antibodies and a longitudinally extended periaortic softtissue structure on CT. Nephron 1998;78:218-20. 
13. Fernandez Guerra J, Cano Gomez S, Soto Campos JG, Valenzuela Mateos F. [Retroperitoneal and mediastinal fibrosis with serum p-ANCA increase. A new evidence of immunological etiology?]. Ann Med Intern 1995;12:622-3. [Article in Spanish]

14. Jghaimi F, Kabbaj A, Essaadouni L. [Takayasu's arteritis and retroperitoneal fibrosis: a case report]. Rev Med Intern 2010;31:e1-3.

15. van Bommel E, Brouwers A, Makkus A, van Vliet A. Retroperitoneal fibrosis and p-ANCA-associated polyarteritis nodosa: coincidental or common etiology? Eur J Intern Med 2002;13:392.

16. Fujii K, Hidaka Y. Churg-Strauss syndrome complicated by chronic periaortitis: a case report and review of the literature. Intern Med 2012;51:109-12.

17. Aslangul E, Ranque B, Papo T. Pseudotumoral retroperitoneal fibrosis and localized vasculitis with very high serum levels of anti-PR3 ANCA. Am J Med 200: 115:250-2.

18. Vaglio A, Manenti L, Allegri L, et al. ANCA-positive periaortic vasculitis: does it fall within the spectrum of vasculitis? J Intern Med 2002;251:268-71.

19. Arlet JB, Le Thi Huong D, Marinho A, et al. Arterial aneurysms in Wegener's granulomatosis: case report and literature review. Semin Arthritis Rheum 2008;37:265-8.

20. Unlü C, Willems M, Ten Berge IJ, Legemate DA. Aortitis with aneurysm formation as a rare complication of Wegener's granulomatosis. J Vasc Surg 2011;54:1485-7.

21. Fink AM, Miles KA, Wraight EP. Indium-111 labelled leucocyte uptake in aortitis. Clin Radiol 1994;49:863-6.

22. Minnee RC, van den Berk GE, Groeneveld JO, et al. Aortic aneurysm and orchitis due to Wegener's granulomatosis. Ann Vasc Surg 2009;23:786.e15-9.

23. Durai R, Agrawal R, Piper K, Brohi K. Wegener's granulomatosis presenting as an abdominal aortic aneurysm: a case report. Cases J 2009;2:9346.

24. Chirinos JA, Corrales VF, Lichtstein DM. ANCA-associated large vessel compromise. Clin Rheumatol 2006;25:111-2.

25. Le Thi Huong D, Papo T, Piette JC, et al. Monthly intravenous pulse cyclophosphamide therapy in Wegener's granulomatosis. Clin Exp Rheumatol 1996;14:9-16.

26. Dufour JF, Le Gallou T, Cordier JF, et al. Urogenital manifestations in Wegener granulomatosis: a study of 11 cases and review of the literature. Medicine (Baltimore) 2012;91:67-74.

27. Gonzalez Revilla EM, Fernandez AA, Ramirez MT, et al. Retroperitoneal fibrosis with periaortitis: A case report of an unusual form of presentation of granulomatosis with polyangiitis. Respir Med Case Rep 2016;19:121-4.

28. Izzedine H, Servais A, Launay-Vacher V, Deray G. Retroperitoneal fibrosis due to Wegener's granulomatosis: a misdiagnosis as tuberculosis. Am J Med 2002;113:164-6.

29. Lomborg N, Marcussen N, Junker P. Retroperitoneal fibrosis as the presenting manifestation of IgG4-related disease in a patient previously diagnosed with granulomatosis with polyangiitis (Wegener's): one disease or two? Scand J Rheumatol 2014;43:345-7.

30. Khosroshahi, A, Carruthers MN, Stone JH, et al. Rethinking Ormond's disease: "idiopathic" retroperitoneal fibrosis in the era of IgG4-related disease. Medicine (Baltimore) 2013;92:82-91.

31. Metselaar HJ, ten Kate FJ, Weimar W. Ureter obstruction as a complication of Wegener's granulomatosis. Eur Urol 1985;11:63-4.

32. Umemoto A, Ikeuchi H, Hiromura K, et al. Hydronephrosis caused by a relapse of granulomatosis with polyangiitis (Wegener's). Mod Rheumatol 2012;22:616-20.

33. Farpour F, Abrudescu A. A case of granulomatosis with polyangiitis causing hydroureter and hydronephrosis. Case Rep Rheumatol 2014;2014:713957.

34. Kamar N, Malavaud B, Alric L, et al. Ureteral stenosis as the sole manifestation of Wegener's granulomatosis. Urology 2003;62:352.

35. Davenport A, Downey SE, Goel S, Maciver AG. Wegener's granulomatosis involving the urogenital tract. Br J Urol 1996;78:354-7.

36. Middleton G, Karp D, Lee E, Cush J. Wegener's granulomatosis presenting as lower back pain with prostatitis and ureteral obstruction. J Rheumatol 1994;21:566-9.

37. Adelizzi RA, Shockley FK, Pietras JR. Wegener's granulomatosis with ureteric obstruction. J Rheumatol 1986; $13: 448-51$.

38. Leche J, Feuilhade C, Ferroir JP, et al. [Wegener's disease of urologic and neurologic onset]. Ann Med Interne (Paris) 1985;136:353. [Article in French]

39. ter Maaten JC, Franssen CF, Daenekindt AA, Hoorntje SJ. Triple Wegener's granulomatosis in the urogenital tract. Nephron 1993;63:358-9.

40. Baker SB, Robinson DR. Unusual renal manifestations of Wegener's granulomatosis. Report of two cases. Am J Med 1978;64:883-9.

41. Lillaz J, Bernardini S, Algros MP, et al. Wegener's granulomatosis: a rare cause of hydronephrosis. Case Rep Med 2011;2011:814794.

42. de Roux-Serratrice C, Serratrice J, Granel B, et al. Periaortitis heralding Wegener's granulomatosis. J Rheumatol 2002;29:392-4.

43. Hensle TW, Mitchell ME, Crooks KK, Robinson D. Urologic manifestations of Wegener granulomatosis. Urology 1978;12:553-6.

44. Rich LM, Piering WF. Ureteral stenosis due to recurrent Wegener's granulomatosis after kidney transplantation. J Am Soc Nephrol 1994;4:1516-21. 